\title{
Soekarno's View of Indonesian Women The Memoir of Sarinah: A Critical Feminist Discourse Analysis
}

\author{
Wiwik Sundari ${ }^{1}$, Suyanto $^{2}$ \\ wiekku@yahoo.com ${ }^{1}$, suyanto@undip.ac.id \\ ${ }^{1}$ English Department, Humanities Faculty, Diponegoro University, Semarang, 50275, \\ Indonesia, ${ }^{2}$ Indonesian Department, Humanities Faculty, Diponegoro University, Semarang, \\ 50275, Indonesia
}

\begin{abstract}
This study is aimed at: (1) explaining Soekarno's views about women in Sarinah's memoir by Ir. Soekarno and (2) describing the portrait of Sarinah, a woman who lived during the independence period. Both of these aspects were explained in the frame of sociocultural factors that cause sexism in Sarinah's memoir. The material object of this research is a memoir entitled Sarinah, by Ir. Soekarno, the first president of Indonesian Republic. The formal object of this research is the use of Indonesian in the perspective of critical feminist discourse analysis from the Sara Mills Model. The data were collected by applying note-taking techniques and literature studies to capture the data of social identity, knowledge, and author's beliefs and literature to obtain the data of the social, institutional, and situation of the birth of the memoir. The data were analysed by reducing, displaying, and verifying it followed by interpreting the theory and summarizing the result using Sara Mills's feminist stylistic theory and Teun van Dijk's social cognition theory.
\end{abstract}

Keywords: language usage, language sexism, Sarinah, Soekarno, Sarinah figure

\section{Introduction}

An opus, a memoir or literature work, is a reflection of the socio-culture life of the place where and the time when it was created along with its writer's point of view related of a particular point, such as gender. A particular socio-culture environment full of gender hegemony practices will be recorded in the created opus. The existence of gender inquity that has penetrated into all life aspects will also be represented in a literature work or its memoir [1]; [2]. A memoir or literature work as a potrait of the era of its creation is delivered using language as its delivery medium. This memoir uses Indonesian language to depict the socio-culture life of a particular woman who lived in Indonesian independent era.

The language of this memoir or literature work shows a woman figure and its gender relation through her character, profession or occupation, status, or life sacrifice. Meanwhile, the language of this literary study proves the existence of a particular woman stereotype that must be complied into patriarchy system [3]. However, a specific study on a memoir written by a prominent public figure like the first president must be done to understand and explain the writer's perception of a particular woman in his work. The writer's perception is a combination of the common perception of male and tradition toward women.

The memoir in this research is written by Ir. Soekarno, the first president of Indonesian Republic, entitled Sarinah: Kewajiban Wanita dalam Perdjoangan Republik Indonesia or 
Sarinah (Sarinah: Woman Obligation in Indonesian Republic Struggle -for Independency- or Sarinah). It is analysed using a feminist stilystics discourse analysis from Sara Mills [4]. This approach is choosen as it is not only focus on the linguistics feature level of a work but also explain what lies behind those linguistics feature level such as the communication practice or language act and a social practice. It is done by describing and explaining how sexism is shown in the discourse level and then elaborating it with the writer's social identity and socio-culture factor.

Darweesh dan Gayadh (2016) research reveals the realtion of ideology and power in three different levels, word, phrase or sentence, and discourse. Meawhile, Budiwati dan Wijana (2004) research analyses the gender bias level among ethnics. Indonesian language speakers whose ethnics were composed of Javanese and non Javanese shows different gender bias level on the use of terms related with gender aspect in Indonesian language [5].

Those two researchs are in line with Graddol dan Swann [6] three relation of language and gender, saying that: 1) language reflects social classification and gender inequality, 2) the social classification and gender inequality are formed by a sexist language act, 3) the two processes are mutually influencing and researcher must investigate the relation between language and gender.

Feminist stylistics is developed by Sara Mills [7] as part of critical discourse analysis involving stylistic and gender as its main topics to be discussed. For feminist stylistics, Mills developes critical discourse into three analysis levels, word, sentence and discourse. This study focuses only on the discourse level analysis which covers four different section: 1) characterization analysis or a role which inverstigates the gender construction of each role, 2) fragmentation analysis or a role which discusses how women are represented in the text, 3) vocalization which describes text point of view, and 4) schamata or plot/text scheme analysis to know the dominant pattern in narrating gender.

\section{Method}

This is a descriptive-qualitative research which holds a language analysis involving context and non-language matters in a memoir entitled Sarinah: Kewadjiban Wanita dalam Perdjoangan Republik Indonesia (1947) by Ir. Soekarno, the first president of Indonesian Republic. The data were text containing sexism used by the writer to describe women. Those data were collected using Simak Method [8] (Sudaryanto, 2015: 203) and analysed using Padan Method [8]. This research employs Miles and Huberman model [9] (in Sugiyono, 2012) which is done in three steps, data reduction, data display and conlusion/verification.

\section{Results and Discussion}

\subsection{Women According Soekarno}

There are three important life values posessed and used by Soekarno to view Indonesian women. Those are his strong nationalism attitude, his humanism value inherited since his early age and his socialism studied since he was young. Those three fundamental values influence Soekarno's political attitude.

The first value, nationalism, was formed since he was still young. It was indirectly formed through patriotic stories told by his mother, Idayu, who often comfort little Soekarno with patriotic strories of the struggle of his ancestors -who are war veterans- against the Dutch collonials. His mother's ancestor was a soldier who were killed in the battle called Puputan War 
against the Dutch collonials to defend King Singaraja kingdom in Bali. So does his father's ancestor [10].

The second value, humanism, was obtained from his nanny in which the story was written in a book entitled Sarinah. Mbok Sarinah, the way Soekarno called her, was a maid and a nanny. Sarinah gave him humanism value through her advice to love people, particulalrly the poor ones.

The third value, socialism, was obtained while he was studying in HBS school in Surabaya and also when his parents made him stay with H.O.S Tjokroaminoto [11] (Wisnuwardhana, 2015: 59-63). At the moment, Soekarno met many world figures and Western thinkers such as Thomas Jefferson, George Washington, Karl Marx, Lenin, Voltaire, J.J.Rousseau, and many other.

Therefore, it can be said that the most fundamental cause of writing Sarinah is his love toward his country, Indonesia. He wanted a good fate for his country by involving women in political movement. In that way, he thought that women can be placed in a more proper place in the society. Nonetheless, up to now, sexism toward women has not been and cannot be eliminated only by focusing on putting women movement in politics.

\section{Potrait of Sarinah, Women in the Era of Indonesian Independence}

This section describes the socio-culture factor which forms sexism in Sarinah. It was traced by the women life description in the society and the gender construction at the moment the era. The first socio-culture factor is the change of patriarchy culture interpretation. The patriarchy culture is previously applied to make the society more civilized than the matriarchy culture as the matriarchy culture was considered less civilized since the relationship between men and women is more unclear than that of the patriarchy culture.

However, a negative impact emerge in the development of patriarchy culture when men has a particular desire to fulfill all his need and to posses something for their own sake. Since then, men starts to treat women as less valuable human being than men. They feel more powerful and more superior than women. This phenomenon continues until the Indonesian independence era where women were placed in an inferior position whose fate were determined by men. Men feel that they have the right to set women' life, while women were obliged to accept all men' decision.

The second socio-culture factor is women' role in Javanese patriarchy culture which is positioned by the society as Konco Wingking. This factor reflects Soekarno's exposure of Javanese culture as he lives in Java island. The literal translation of konco wingking is a life companion who stays behind [12]. In gender equality, this concept reflects the discrimination of women' existence where men considered more suitable to lead than women and always serves as a single and major parameter of husband and wife relationship. This concept depicts women' passive role in the house as housewives where men never involved women in any public affairs as they think that women do not have any competence in handling it well since most of them were also less educated due to their limited chance of getting education. Women role as konco wingking is found in Indonesian independence era when Soekarno starts to think about women' role. Although this consept is rejected by him, the sexism he used in Sarinah proves that he is still unconsciously influenced by the concept which is reflected from the element use and choice in the text.

The third socio-culture factor is women do not aware of the unfair condition applied to them by the society. Instead of fighting against a concept underestimating their life value, women themselves consider konco wingking concept as a proper one. Only few women realize men subordination toward them. According to Soekarno, there are different levels of women 
movement based on their self awareness. To him, women were still in the first level of self awareness of household affairs under patriarchy system. Soekarno wishes women higher self awareness resulted in an advanced movement for their own freedom of life and their nation development through women political movement.

Those three factors become the socio-culture factors that formed and construct the gender unequality in sexims practices Sarinah.

\section{Conclusion}

There are three social identity causing sexism on women in Sarinah. First, Soekarno only focusing his view on women movement in politic for his patriotic spirit toward his country. Second, Soekarno still wants to keep the patriarchy culture but he said that it must be done based on equal justice for all sex. Third, Soekarno adores women beauty that influence his point of view toward women.

There are three socio-culture factors constructing gender in the era of Sarinah was written and published that was possibly serves as the cause of sexism in the memoir: 1) the men superior feeling, 2) the women role as konco wingking, and 3) the women self awareness toward their unfair condition that has not been emerged.

\section{References}

[1] Sunardi, "Diferensiasi Linguistis Berdasarkan Gender dalam Teks Sastra Inggris", dalam Linguistisa. Vol.14/27 (2007)

[2] T.R. Budiwati and I.D.P. Wijana, "Bias Gender dalam Bahasa Indonesia" dalam Humanika. Vol.XVII/2( 2004)

[3] M. Muzakka, "Perjuangan Perempuan Melawan Hegemoni Patriarki: Kajian terhadap Novel Perempuan Berkalung Sorban”, Kajian Sastra, Vol.34/2, Hal. 128-138 (2011)

[4] S. Mills, The Interface Series: Feminist Stylistics. London: Routledge (1995)

[5] T.R. Budiwati and I.D.P. Wijana, "Bias Gender dalam Bahasa Indonesia" dalam Humanika. Vol.XVII/2 ( 2004)

[6] D. Graddol and J. Swann, Gender Voices, Telaah Kritis Relasi Bahasa-Jender. Terj. M. Muhith. Pasuruan: Penerbit Pedati (2003)

[7] S. Mills, The Interface Series: Feminist Stylistics. London: Routledge (1995)

[8] Sudaryanto, Metode dan Aneka Teknik Analisis BahasaPengantar Penelitian Wahana Kebudayaan secara Linguistis. Yogyakarta: Sanata Dharma University Press (2015)

[9] Sugiyono, Metode Penelitian Bisnis. Bandung: Alfabeta (2012)

[10] S. Wisnuwardhana, Sarinah: Mata Air Cinta, Humanisme, dan Feminisme Soekarno dalam Pelukan Cinta Sang Ibu Asuh. Yogyakarta: PALAPA (2015)

[11] C Adams, Bung Karno-Penyambung Lidah Rakyat Indonesia. Jakarta: Yayasan Bung Karno (2014)

[12] W Sahayu, "Adjective Check List Pengungkap Stereotip Laki-laki dan Perempuan Menurut Persepsi Mahasiswa dari Sepuluh Etnis”. Litera, vol 10, No.2 (2011) 